\title{
UNEP（国連環境計画）
}

\section{UNEP の概要}

\section{1 設立}

UNEP は国連の組織としては新しいものであ る。よく知られているように，1972年 6 月 $5 \sim 16$ 日にストックホルムに执いて世界113か国の参加 を得て開かれた国連人間環境会議の決議を受け て，同年第27回国連総会に掞いてその発足が決定 され, UNEP (United Nations Environment Programme：国連環境計画）の略称で活動を開 始した。

国連では, 以前からWHO (世界保健機関), ECOSOC (経済社会理事会) 等の機関によって環 境問題の調査検討を行っていた。1968年の ECO$\mathrm{SOC}$ 第44回会議のスウェーデン提案が, 同年第 23 回国連総会に打いて，「人間環境に関する国連会 議」の開催決議となって結実し，4年の準備期間 の後, 前述のようにストックホルムで開かれ, 有 名なスローガン "かけがえのない地球 : Only One Earth" のもとで幾つかの決議が採択された。

7 条から成る主文と，26項目の原則で構成され た格調高い「人間環境宣言」, 109 に及ぶ行動計画を 示した「世界環境行動計画」に続いて,「環境問題の 国際機構の設立」等の決議であるが, これらの決 議を反映したのが, UNEP の発足である。

\section{2 組織と運営}

UNEP の本部はケニアのナイロビに置かれ，管 理理事会, 環境事務局抒よび環境基金によって構
成され，事務局の組織は第 1 図のようになってい る。管理理事会の理事国は日本を含めて，58か国 で構成され，環境基金に対する拠出国は100か国, 1981年の例では米国998万ドル，日本400万ドル， ソ連370万ドルとなっていた。

管理理事会は最高政策決定機関であり, 年 1 回 本部で開かれているが，1982年はストックホルム 国連人間環境会議 10 周年の特別会合が加光られ て，いわゆる「ナイロビ宣言」が発表された。10 年前の “かけがえのない地球”に対して, “我々の 小さな惑星 : Our Small Planet" という言葉が用 いられ,「1982年の環境, 回顧と展望」6 章と共に 採択されたものである。

管理理事会本会議はこの特別会合に引き続いて 開かれているが，この一連の会議で日本政府代表 原環境庁長官の「地球の環境保全に関する諸施策 を長期的かつ総合的な視点から検討する機関とし て，私は将来の環境政策のための指針を提示する 特別委員会の新設を提案したいと思います。」とい ら演説に始まる日本の環境外交は, 各国の大きな 反響を呼んだ。この提案は最終的には次回以後の 管理理事会の継続審議となったが, 各国の反対や 賛成执よび基金問題等, UNEP の運営の難しさを 反映したが，日本が環境問題に打いて，リーダー シップを示す時代になったのも事実である。

環境基金についても，日本が第 2 位の拠出国で あり（57年末までに総額 2 億 5,113 万ドル，5ち日 本は2,790万ドル), 北欧諸国が負担率を増す提言 がある一方で，第 1 位の米国に減額の動きがある

*つちや いわ抢 国立公害研究所環境情報部 業務室長 


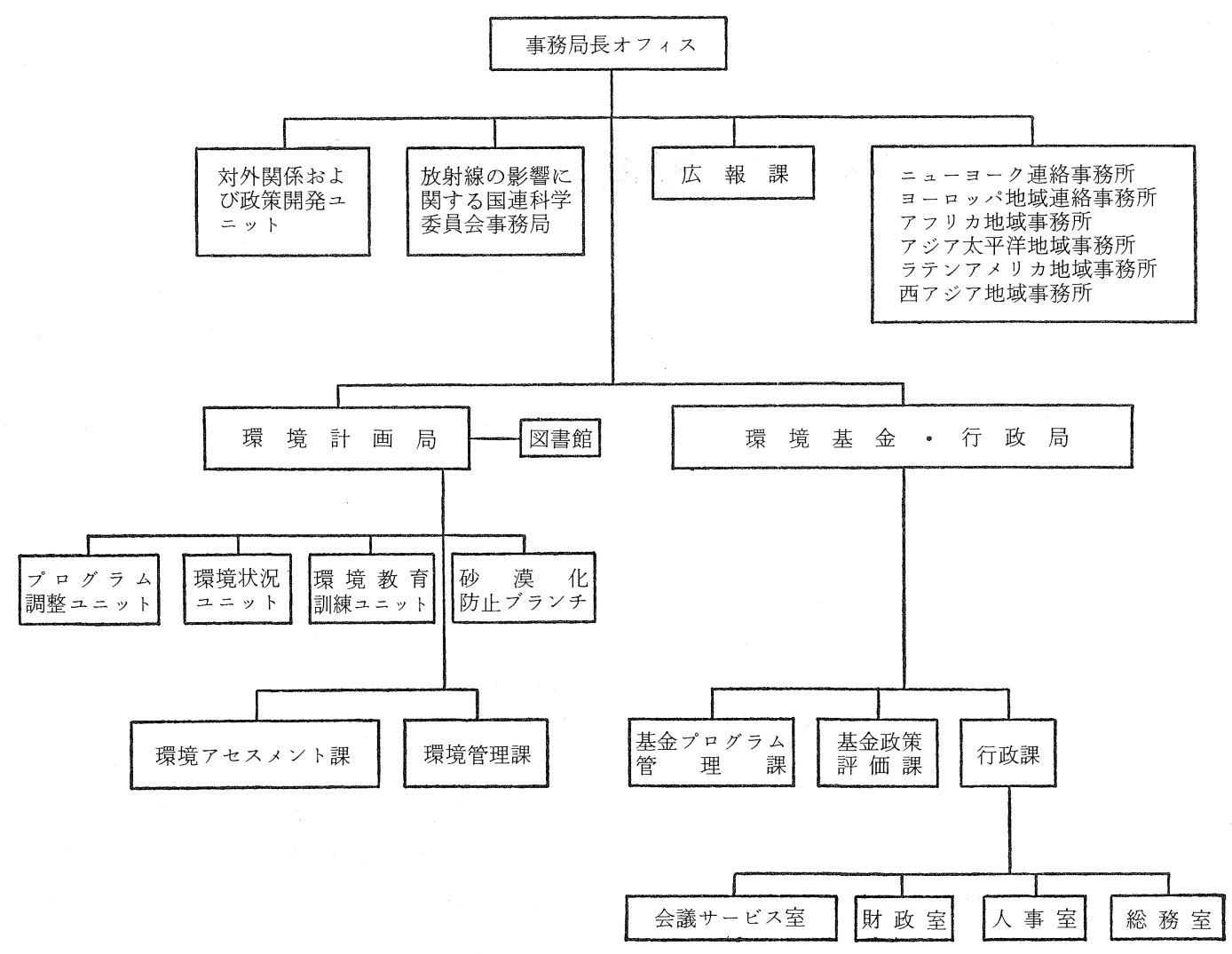

第 1 図 UNEP の機構

という面もあって, やや不安定であるが発展途上 国の UNEP に対する期待は増加している。

事務局長は第 2 代目のエジプトのモスタファ・ $\mathrm{K} ・$ トルバになり, 各部局に加盟各国から出向の職 員約 100 名がいるが, 日本からは数名であり拠出金 額から見ても多いとは言えない。

\section{3 他の国際機関との関係}

環境問題については，以前から国連の幾つかの 機関が活動していたといら事情もあって, UNEP はそれらの機関の環境保全のためのプロジェクト の促進と調整的機能を果たしている。調整は制度 的には, ECB (環境調整評議会) が国連総会の下 部組織として存在するので, 国連各機関の環境関 連のプログラムはこの ECBを経由して調整され る。したがって以前から幾つかの環境プロジェク トを進めてきたFAO（国連食糧農業機関）や
WHO（世界保健機関）などの機関との共同プロ ジェクトでは, ECB と UNEP 事務局との連絡を よくする必要があった。当初, UNEP 外にあって あまり機能していなかった ECB も, UNEP 事務 局の精力的な働きかけで, ILO, UNCTAD, WMO, IMCO その他の国連機関を含めて横の連 絡が年々改善されてきている。調整のための会合 の事務局もUNEP 事務局が担当するといら形 で，調整機能の実があがりつつあるといえる。

国連機関とは別であるが, $\mathrm{OECD}$ (経済協力開発 機構）との関係も重要である。24の先進工業国に よって構成されたこの機関の活動目的に

1）最大の持続的経済成長と雇用の達成並びに 生活水準の向上

2）加盟国掞よび非加盟国の健全な経済生長へ の貢献

3）世界貿易拡大への寄与 
がある。この目的に沿って, 1960年代の環境問題に 対する認識の発展に伴い, 1970年代には環境委員会 が従来の科学政策委員会の一部門から昇格して設置 され，1981年委での間にPCB規制の決定や污染者 負担原則 (いわゆる PPP)の勧告などが行われた。 OECD の決定は加盟各国に対する拘束力があり, 環境委員会の調査研究の成果は出版物として公表 され，国際的な影響力も大きい。1976一77の日本 の環境政策レビュー（邦訳名：日本の経験一環境 政策は成功したか) では, 経済活動に著しい影響 を引き起こさずに1960年代の深刻な公害問題を克 服したことを評価している。現在, OECD と UNEP との間では人的交流等を通じ次第に協力 関係が深まりつつあると言われている。

\section{UNEP の活動}

\section{$2.1 \mathrm{UNEP}$ のプロジェクト}

UNEP は他の国連機関に比べて, 歴史が浅いと いうより，できたばかりで，環境関連活動につい て，他の機関に対し指導・調整・促進の役割を持 つといら大役があった。100人そこそこの事務局で それを果たすのは至難のことであり，現実には自 ら実施する内部プロジェクトと他の機関等が実質 的な活動をする外部プロジェクトに分けて事業を 進めているのが現実である。

UNEP のプロジェクトは, 環境分野の研究調 査, 国際会議, セミナー, シンポジゥム等の開催, 教育・訓練プログラムの補助と出版物の刊行とい らように活動の幅が広い。他方, 事務局の職員の 数は少なく，それぞれのプロジェクトごとの専門 家もそろっていないといら事情のため, 事務局が 実施する内部プロジェクトも，かなり外部委託の 形をとることが多い。

主要プログラムの中から情報活動に関係の深い ものを挙げると, 環境アセスメントの分野の中に, 地球監視 (Earth Watch) と環境データ (Environmental Data）がある。地球監視はさらに

1）世界環境監視システム（GEMS：Grobal Environmental Monitoring System)
2）国際情報源照会制度（INFOTERRA）

3) 国際有害化学物質登録制度 (IRPTC) に分かれ，いずれも内部プロジェクトである。

これらの中で INFOTERRA が UNEPらしい 特色をもって活動して抒り，日本の役割もはっき りしているが後にやや詳しく説明するので，ここ ではGEMS とIRPTCを簡単に紹介する。

\subsubsection{GEMS}

GEMS は, 効果的な環境管理のための必要な データを収集するために, UNEP と他の国連機関 执よび世界各国との間の共同事業となるよらに考 えられていた。しかし，データの収集・解析とも に公開を前提にして初めて成立するため, 国と国 との利害関係を反映するなどして, 計画の進行は かなり遅れたが，関連の国際機関との協定が整い 次第公表されつつある。当初は泒染モニタリング が動き出し, 次いで生態系モニタリングの計画が 進みつつある。1979年ごろの状沉を略述する。

A）污染モニタリング

(1) 健康関連モニタリング

(a) 大気污染モニタリング

WHO が中心になって, UNEP と WMO (世界 気象機関) が支援し, Air quality in selected urban area の名称で年報形式のものが, WHO Offset Publication シリーズの中で発行されてい る。また, $\mathrm{OECD}$ も $\mathrm{SO}_{2}$ の長距離輸送について調 査結果をまとめつつあり, インドのナグプールに ある国立環境工学研究所が UNEP の援助によっ て幾つかの調査をまとめている。

(b) 水污染モニタリング

WHO, WMO, UNESCO, UNEP, FAO 等の 協力で進行し, また $\mathrm{OECD}$ も内陸水の富栄養化防 止のためのモニタリングに着手している。

(c) 食物㐨よび飼料モニタリング

FAO とWHO が中心になって，1977年にパイ ロットスタディを開始した。

(d) 特定対象中の污染物質モニタリング

UNEP と WHO の協力に加之て以前から行っ ていた IAEA (国際原子力機関), UNSCEAR (国 連放射線影響委員会) の調查も含まれるように 
なっている。

（2）気候関連モニタリング

(a) 気候モニタリング

1967年 WMOによって開始されたWWW (ワールドウェザーウォッチ), そのほか世界 1 万 以上の気候観測ネットワーク, 600以上の太陽放射 観測網、をた1963年以来世界21か国70点以上の才 ゾン観測網，WMO と ICSU (国際学術連合会議) の協力で始められた気候変動モデルのためのモ二 タリング，さらに UNESCO が1960年以来進めて きた氷河の質量収支および変動モニタリングなど 次々にUNEP が支援する形になっている。

(b) 気候変動に関連した污染物質モニタリング WMO は1970年にバックグラウンド大気污染 のうち, 天気と気候に影響を与えるものについて 世界的観測網の樹立に着手したが, UNEP は1974 年以来協力しているし，オン゙ン研究拉よびモニタ リングについても同様のことが進められている。

(3) 海洋モニタリング

(a) 地域海水域モニタリング

地中海についてはUNEP 主導で, FAO, IOC (政府間海洋学委員会), WHO, WMO, IAEA 協 力の形で開始され, 北海では ICES(国際海洋開発 評議会）の1967年以来の情報収集がさらに強化さ れた形になり，バルト海と北東预よび北西大西洋 について沿岸各国を中心にして作業が進んでい る。

(b) 大洋のモニタリング

IOC とWMO の共同事業としてIGOSS（世界 総合海洋観測所システム) が進み, さらにWMO のWWW がそれを補完する気象観測サービスに 拡大し, UNEP が参入しての IGOSS 石油污染モ ニタリング・パイロット・プロジェクトが着手さ れ, UNESCO の海洋に注ぐ世界河川登録や, 開放 海域に怙けるバックグラウンド泒染モニタリング 計画のように IOC, WMO 抒よび UNEP の共同 事業のようなものもある。

B）生態系モニタリング

(1) 世界の土壌掞よび植生モニタリング

(a) 世界的土壤劣化の把握
UNEP 協力, FAO と UNESCO 共同事業で, ア フリカについて作業が進んでいる。

(b) 熱帯森林モニタリング

UNEP 援助, FAO 実施であるが, ランドサット などの人工衛星の活用が前提となっている。

(c) 遊牧地モニタリング

UNEP 援助, FAO 実施, 1977年開始のもので, UNESCO そも類似の計画がある。

（d）世界の農業生態学的地域別土地資源の潜在 力評価

FAO の1976年よりの 3 か年計画である。

(2) 水資源モニタリング

(a) IHD（国際水文学10年）とIHP（国際水文 学計画)

IHD は1974年に終わり, 続いて IHP が始まり UNESCO から関連報告書が出版されている。

(b) 実用水文学のためのモニタリング・サービ ス

WMO が調整機能を果たしつつあるもので, データ処理が中心になっている。

(c) 世界水河インベントリー

IHD 期間にUNESCO が着手したものに, UNEP と国際雪氷委員会が協力している。

(d) ヨーロッパの水収支に関する国際協力

UNESCO と WMO の共同事業として進行。

(e) 降雨中のアイソトープ世界調査

IAEA の1961年以来の事業で, 世界65か国100以 上の気象観測所のデータを収集刊行している。

(3) 生物圏モニタリング

(a) $\mathrm{MAB}$ (人と生物圈) 事業計画

1971年 UNESCO が開始したもので, 35か国118 の生物圈保護区の設定などが進行している。

(b) 野生生物サンプリング計画

OECD が1972一75の調查によって14か国の生 物中の PCB, DDT 等のモニタリングしたものを まとめる計画がある。

(c) 野生生物モニタリング

IUCN (国際自然保護連合)が絶隇の恐れがある 野生生物のモニタリングとして進めている。

(d) 残留農薬モニタリング 
主に開発途上国を対象にして，FAO と UNEP の協議により進められている。

（4） 海洋生物資源モニタリング

ICES (国際海洋開発協議会) が北東大西洋, 北 極海，バルト海について進めている。

C）自然災害モニタリング

（1）熱帯低気圧モニタリング

WMO が中心となってリアルタイムモニタリ ングの整備に努めている。

（2）国際津波情報センター

IOC がホノルルの太平洋津波警報センターと 協力しながら，国際的に発展させる計画になって いる。

\section{（3）洪水予報}

WMO が WWWを利用して洪水予報を効果的 にする作業を進めている。

以上の説明でも理解されるように, GEMS は壮 大なプロジェクトであり, 現在も内容の追加更新 が行われている。UNEP の内部プロジェクトとは 言っても，実態は大部分が既存の有力あるいは実 力機関が実施しているものにUNEP の名前が加 えられたという印象が強い。したがって，成果の 公刊もそれら実施機関に頼ることが多いので, 情 報の入手も UNEP 経由でなく, 個々の実施機関 によって可能になることが多い。

\subsubsection{IRPTC}

IRPTC はUNEP の内部プロジェクトではあ るが，WHO本部の建物内で事業を実施し, UNEP の環境基金から経費が支出される形に なっている。例壳ば, 1981年度はIRPTC Phase II の名称で約 80 万ドルが支出された。

IRPTC は1975年の第 3 回 UNEP管理理事会 で，その活動計画を推進する計画実施センター (PAC : Programme Activity Centre) の設立が 認められ, UNEP 本部内に事務局が設置されたの が始まりである。このセンターは1976年 8 月に UNEP とWHO の協議によって, スイスのジュ ネーブにあるWHO の本部内に移され, 事業の実 行部門はWHO が担当することになった。そし て, IRPTCの UNEPの諸事業の中での位置づ

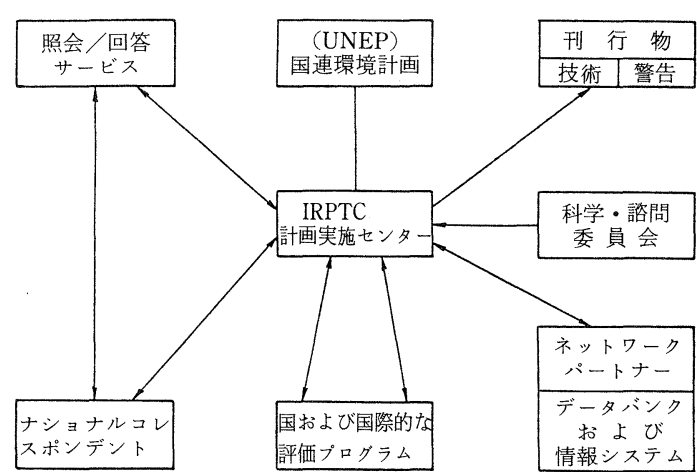

第 2 図 IRPTC の組織概要

け，活動目標等はその後毎年の UNEP 管理理事 会で審議され決定されるよらになった。IRPTC は次の 4 項目を目的とした機関であり，そのため に第 2 図に示した組織になっている。

（i）ヒト招よびその環境への化学物質の影響に 関する現存のデータへの接近を容易にし，それ によって化学物質㘧よびそれらの規制の影響の 評価のため利用できる国掞よび国際的な資源の さらに効率的な使用に貢献する。

(ii）登録の情報に基づき，化学物質の影響に関 する現在の知識に打ける重要な欠陷を確認し, これらの欠陥を埋めるため研究の必要性に対す る注意を喚起する。

(iii) 化学物質による有害性の可能性を確認する か，またはその確認を助け，そしてこのような 有害性の認識を改善する。

(iv) 有害な可能性のある化学物質の規制のた め，国，地域㧍よび世界的方針，規制方法並び に基準および勧告に関する情報を与える。

この組織ではIRPTCのPACすなわち計画実 施センターは，国を代表するナショナルコレスポ ンデント (NC : National Correspondents)やネッ トワークパートナー（NP : Network Partner) としての IPCS (International Programme on Chemical Safety：国際化学物質安全性計画）な どから，有害化学物質に関連した登録を受けると ともに情報の交換をする。IPCS は WHO, ILO お。 よびUNEPを共同母体にして1980年に発足した 組織である。一方，収集整理したデータに基づく 
照会・回答サービスを行うため, データバンクと しての機能を持つという特色がある。

ネットワークに組み入れられているのは，その ほか後述の INFOTERRAをはじめ, ECE（ヨー ロッパ共同体委員会), FAO, IAEA(国際原子力 機関), IARC (国際癌研究機関), WMO (世界気 象機関), ECDIN (環境化学データ情報ネットワー ク), OECD など20近い国際機関がある。また,ナ ショナルコレスポンデント (NC) も1979年に日本 では厚生省国立衛生試験所（担当は化学物質情報 部)が指定され，1981年には90か国100機関以上に なった。 NCの機能は次のようになっている。

1）その国の化学物質, 化学物質に関する事故, 特よび関心のある化学物質について, 関連の知 識,クライテリアドキュメント（Criteria Document), レビューおよびモノグラフ, デー タバンク和よび情報システム，法律扔よび規則 に関する情報をIRPTC に提供する。

2）照会回答サービスの発達を助ける。

3）その国に颃いて IRPTC 拉よびその仕事に ついての情報を配布する。
これは, 当初IRPTC が計画した機能が過重で あるとしたための暫定的な取り決めと見られてい る。

IRPTC は信頼性の高いデータバンクを構築す るために，第 3 図に示す 17 項目を入れたデータプ ロファイルを物質ごとに作成して蓄積する作業を 開始し，1982年までに 4 万余の化学物質のファイ ル作業が進行した。農薬関係などヒトの環境保護 に重要なもの約300〜400物質については，絶えず データの追加と更新を行うようになっている。

また, IRPTC の活動状態はIRPTC Bulletin (ISSN 0250-4227, 発行は UNEP-IRPTC-PAC, Palais des Nations, 1211 Geneva 10, Switzerland）によって知ることがでさる。

IRPTC の照会システム利用に際しては, 公開 された制度ではあるが，かなり専門的な分野の データバンクを利用することになるので，それぞ れの国の NCを通して行らのが原則である。情報 検索の方法としては, MEDLINE, TOXLINE, NIH-EPA-CIS, DIALOG のデータベースシステ ムの利用, WHO, ILO, NCなど組織が保有してい

$$
2 \text { 環境データ }
$$

8 法律の規制

4 生産と使用

\begin{tabular}{|l|l|l|}
\hline Environmental Pathways & 5 \\
\hline Environmental Fate Tests & 7 \\
\hline Environmental Fate & Production/Trade \\
\hline Clearance/Metabolites & 環境の濃度 \\
\hline Spencentrations & 毒性データ \\
\hline Studies
\end{tabular}

第 3 図 IRPTCのデータプロファイルの項目の概要 
るデータの利用などがあり, 化学物質の法規制に 関する問い合わせが多いという。

IRPTC にはアメリカの国立職業安全衛生研究 所 (NIOSH) 作成のファイルなど，各国の特色あ るデータが集積されつつあるので，情報の提供シ ステムの改善によって，今後重要な役割を果たす はずである。

\section{INFOTERRA}

INFOTERRA（国際環境情報源照会制度）は前 にも述べたように，UNEPの 3 大内部プロジェク トの一つであり, しかも UNEP 本部で直接実施 している情報活動の一つでもあるので, やや詳細 に説明する。

\section{1 沿革}

GEMSの計画が立てられると間もなく，IRS (Internanional Referral System for Sources of Environmental Information)の略称で, 準備作業
が進められ，1975年に設立，1977年に運用開始と なった。日本の対応としては，発足後間もない国 立公害研究所（1974年 3 月 15 日開所）の環境情報 部職員が何回か派遣されたが，1975年10月には日 本を代表するナショナル・フォーカルポイントと して環境情報部が指定された。直ちに, 日本に抒 ける情報源登録の作業が進められ，同様にして世 界各国から集められた登録票に基ついて作成され た磁気テープを使ら運用システムが1977年に開始 されたわけである。この年12月にナイロビでは日 本を含めた 23 か国のフォーカルポイントの担当者 による技術会議が開かれ，翌年にはナイロビの運 用責任者 P.M.Morse 氏の来日もあって, 関係省 庁担当官との検討も順調に進められた。

その後1979年にはIRSの略称は, INFOTERRA に変更されたが，これは国連の公式用語 のらち英語, フランス語, ロシア語, スペイン語 の 4 か国語の利用者から共通の理解が得られるよ らに配慮されたためと言われている。ちなみに INFOはInformation 等の情報を意味し, TERRA

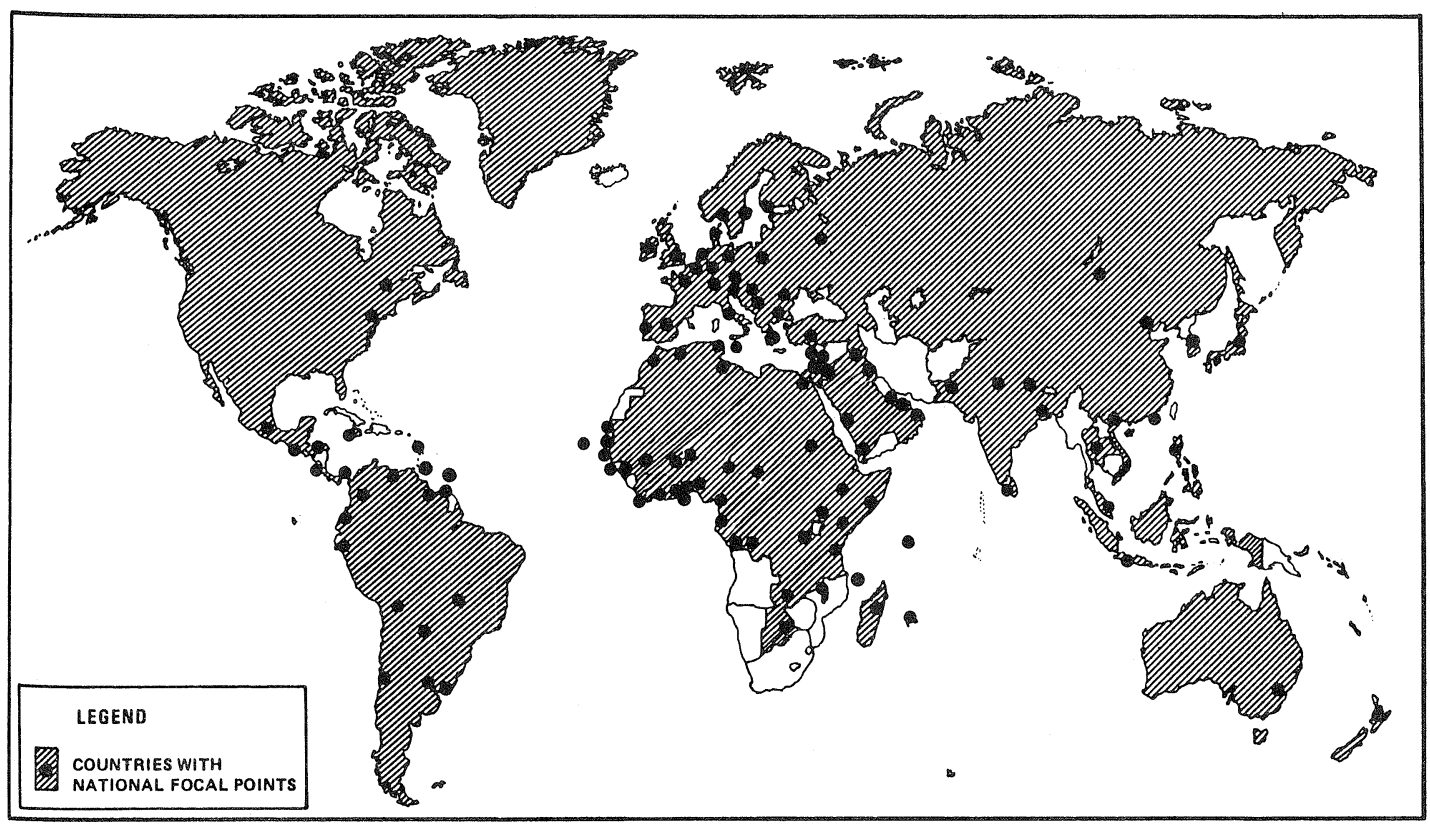

第 4 図 INFOTERRA 参加国（1982年現在） 

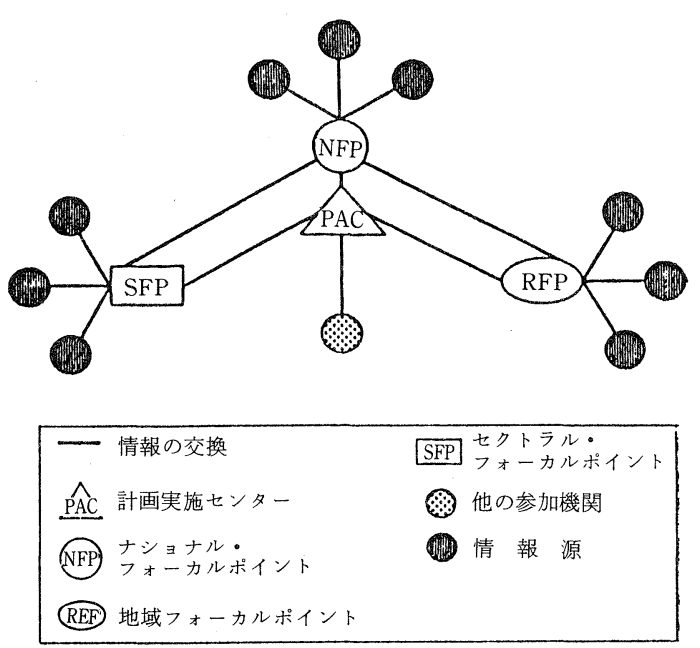

第 5 図 INFOTERRA 機構図

はフランス語やスペイン語で大地を意味するかあ るいはそれに関連する言葉の接頭語として用いら れるものに相当するようであるが，正式な説明は 得られていない。

1982年 1 月現在で, 116か国が参加し(第 4 図参 照), 約 9,700 機関が情報源として登録されており, 日本については1983月 1 月までに212機関が登録 している。

\section{2 組織と活動}

INFOTERRA は第 5 図に示したシステムで構 成されて拈り，ナイロビの UNEP 本部に計画実 施センターPAC (Programme Activity Center) を置いた一種の分散型ネットワークになってい る。具体的な作業としては, 各フォーカルポイン トがその守備領域内で受け付けた登録票をPAC に送り，PAC はそれに基づいて検索用の磁気テー プを作成する。すなわち,

\section{第 1 表 INFOTERRA 情報源の登録内容}

\section{情報源番号（Accession Number）}

1. 国コード

2. 親機関コード

3 ．情報源コード

I . 名称と住所 (Name and Address)
1 . 情報源の名称と住所
2 . 親機関の名称と住所
3 . 国内ューザの問合せ先の名称と住所
4. 外国ユーザの問合せ先の名称と住所

II . 情報源の説明 (Description of Information Source)

英文（またはフランス語，スペイン語，ロシア語）300文字以内

III. 情報源としての特徵（Organizational Attributes）

1.スポンサー (Sponsorship)

2. 親機関の活動内容 (Activities of Parent Organization)

3. 情報源の機能（Functions of Information Source）

IV. 情報の地理的範囲 (Geographical Coverage)

V. 言 語 (Working Language)

VI. 情報提供に関する特徵（Information-transfer Attributes）

1. 情報の提供条件 (Availability)

2. 情報の提供様式（Output）

VII．情報の内容（Subject Attributes）

1. 最も関連の深い分野 (Most Relevant Subject)

2.その他の関連する分野 (Other Associated Subject)

注 : IIIIVIIまではすべて INFOTERRAの定めたキーワード (attributes)によって表されてい る。「情報の内容」を表すキーワードは, 26のカテゴリーにわたり, 約 1,000 個の主題用語 が用意されている。
INFOTERRA の中心に なるデータベースが作成 される。このデータベー スを構成するファイルは 定期的に更新され，更新 ごとにそのコピーが各 フォーカルポイントに送 付され，李たこのファイ ルに基づいて編集された 情報源の台帳として印刷 した INFOTERRA Directory b送付され る。各フォーカルポイン トは送付されたファイル で電算機を用いて検索す るか，印刷物になった台 帳を開いて調べるかの 2 種類の照会作業ができる ことになる。登録票の記 入内容と形式はPAC が 指定するが，第 1 表のよ らになっている。 
第 2 表 登録票に基づいて INFOTERRA のデータベースに入力された内容（英文の部分）

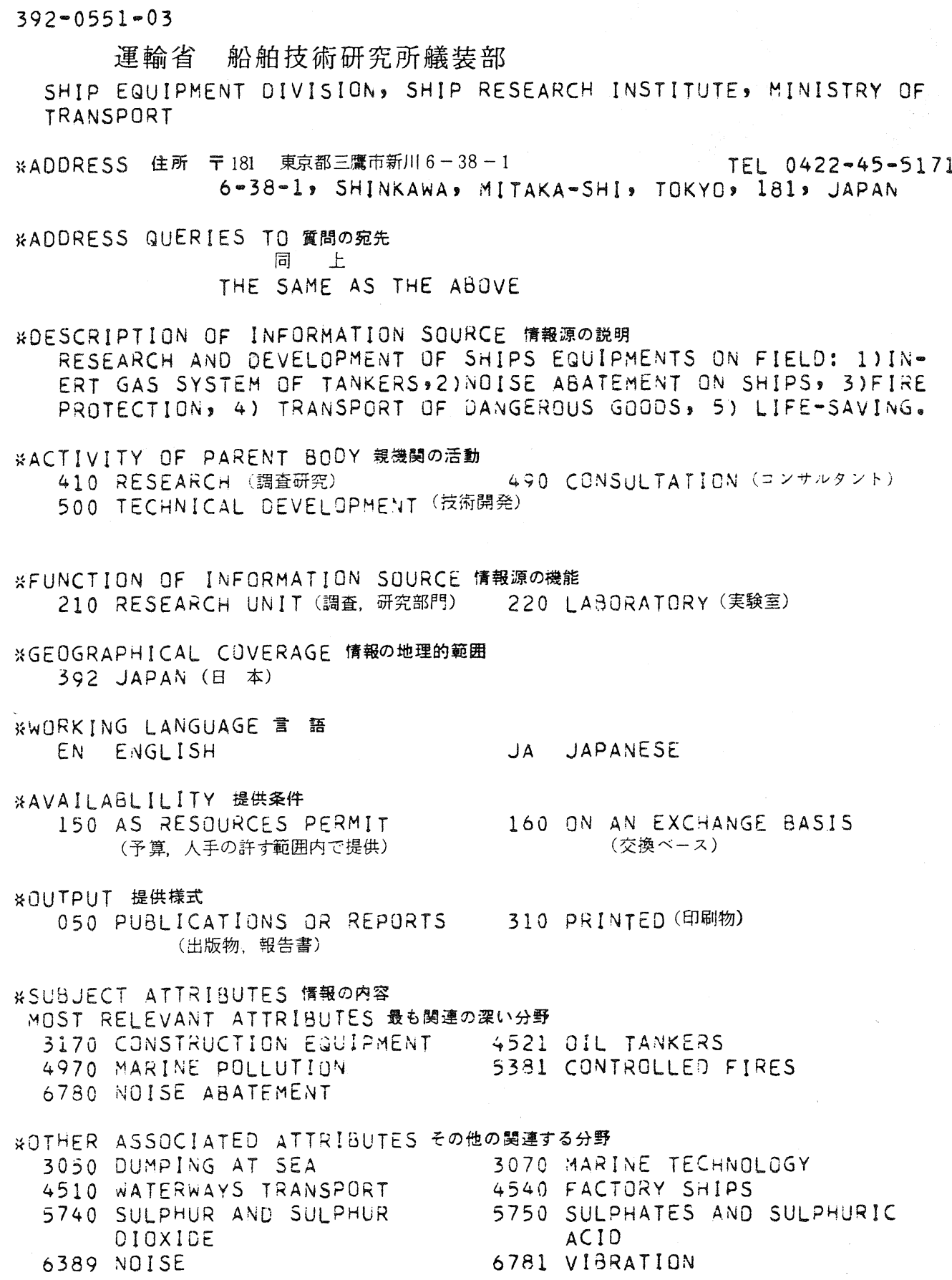




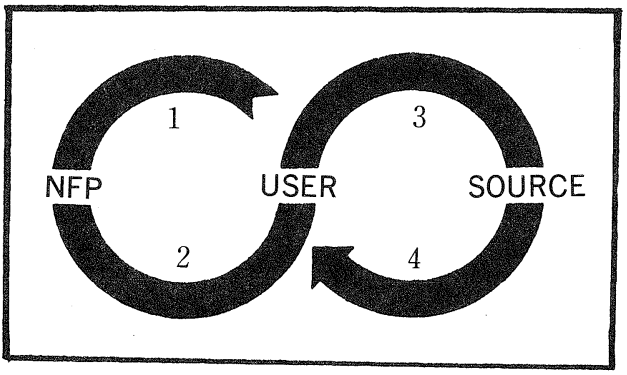

1 : 利用者(User)がナショナルフォーカルポイント (NFP) 亿検索依頼

2：NFPは情報源リストを提供

3：リストから選んだ情報源(Source) そ利用者が直 接依頼

4 : 情報源が利用者に情報を提供

第 6 図 INFOTERRA の情報源照会システム

各情報源の登録票記入に基づく内容の例を第 2 表に示す。

このシステムではフォーカルポイントは情報源 とデータベースを作成する PAC との中継点にな るが，利用の面でもこの特色が生かされる。第 6 図に示したよらに，情報を求める利用者はフォー カルポイントに質問し，得られた回答に示された 情報源となる機関に対して，改めて必要な情報入 手の手続をとる。質問はどのフォーカルポイント に対しても，また本部のPACに対しても可能で あり，原則として無料である。ただし情報源から の原典となる情報の入手に際しては，それぞれの 情報源機関の規則に従ら必要があり，その規則の 説明も質問に対する回答の中に含まれている。

このシステムは情報源を照会するだけで，情報 源を必要とする利用者の 2 段階の手続を前提にし ているため，どうしても時間がかかるし，制度そ のものの理解もそれほど容易でない。このため, UNEP は制度の広報活動には非常に熱心であり, 各フォーカルポイントの管理者間の会議や事務担 当者を地域ごとに集めての技術検討会などをしば しば開いている。

\section{3 フォーカルポイントの役割}

フォーカルポイントは分散型ネットワークの地 方拠点として，直接登録事務を行いまた利用者に
第 3 表 INFOTERRA 国内情報源

\begin{tabular}{|c|c|}
\hline 政府行政機関 & 62 \\
国立試験研究機関 & 32 \\
公立試験研究機関 & 42 \\
特殊法人・公益法人 & 44 \\
国立大学・私立大学 & 32 \\
\hline 合 計 & 212 \\
\hline
\end{tabular}

情報源を回答する役目を持っているだけに， INFOTERRA の中では重要な空口となる部門で ある。データベースの生命は，そこに入れた情報 が常に最新かつ正確であることによって維持さ れ，その基本をなすのが登録作業であるからであ る。

原則として，情報源の登録内容の更新は，登録 票の常時修正に加光て, 登録後 2 年ごとに全体的 な検査をして，再確認の得られないものはファイ ルから削除するという方法がとられている。この 作業では，日本の場合，1982年 3 月までに180機関 が登録され，1983年 1 月末での間に38機関が修正 拉よび新規登録の対象になって, 計212機関になっ た。第 3 表に種類別機関数を示した。米国が3,000 余の機関数を登録しているのに比べて，少ないと 言うこともできるが，制度を理解して登録する機 関は年々増加している。登録機関自体が利用者に なる機会はかなり多いので，長い目で見ることも 必要である。

フォーカルポイントのもら一つの役割，すなわ ら情報源の所在を利用者に知らせる仕事では, 利

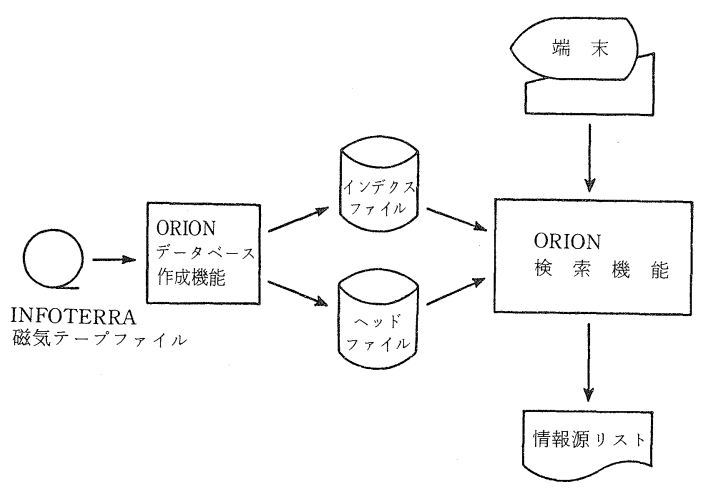

第 7 図 INFOTERRA 情報源のコンピュータによる 検索 


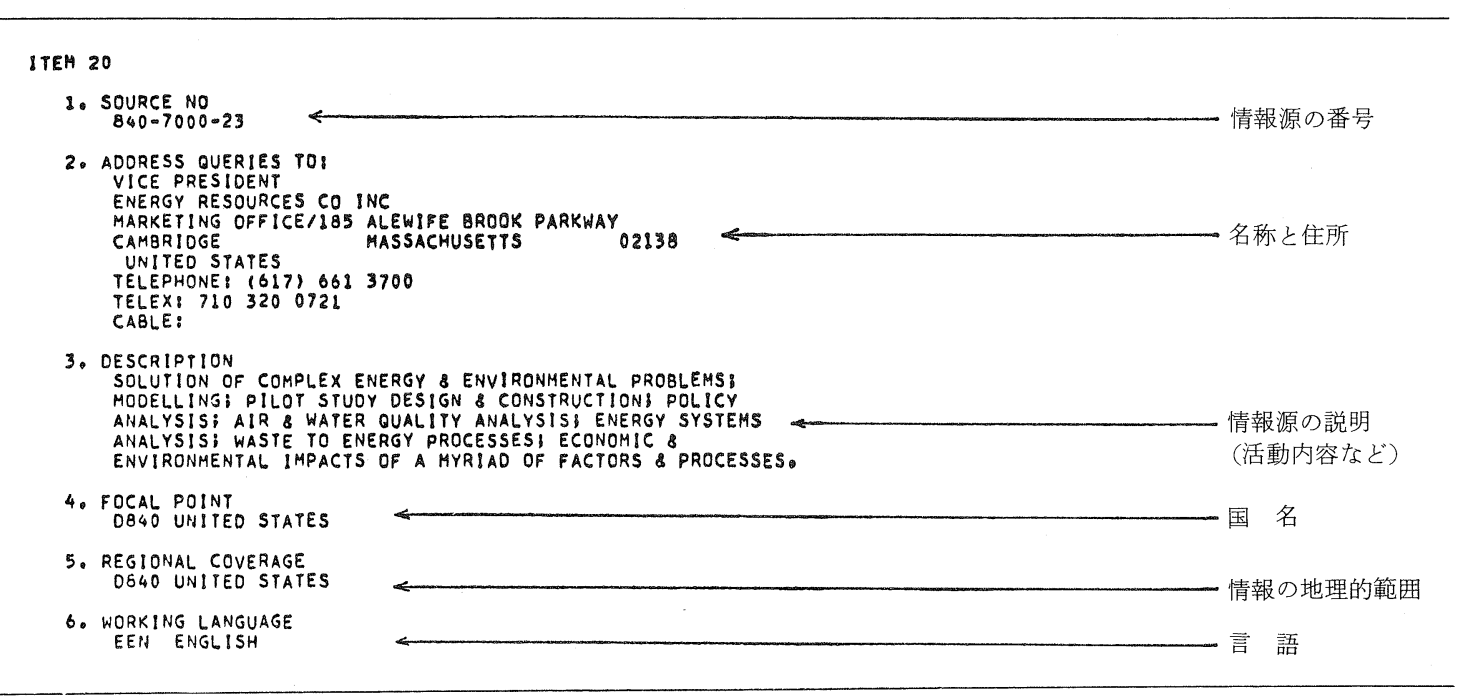

第 8 図 INFOTERRA ファイルの検索出力例（部分）

用者, これは誰でも利用者になれるのであるが， 通常は手紙，電話，テレックスなどによる質問を 受け取ることから始まる。日本では,「国立公学研 究所環境情報部 INFOTERRA 担当者」が宛先に なるが，現在は行政情報についての政府機関の対 応策が改善されつつあるので「国立公害研究所閲 覧の空口」でもよい。閲覧の空口は環境情報部業 務室に置かれて拐り，自動的に質問はINFOTERRA 担当者に回されるようになっている。

担当者はUNEPから送付された磁気テープを 使らオンライン検索をするため，第7図に示した システムを開発して拈り，第 8 図の出力例のよら な回答を出す。質問者が来所して口答で依頼する ことも可能である。この場合には，2段階の情報 収集作業のうち最初のものが短時間で終わること になる。

\section{4 制度の評価}

UNEP の経費を使うものの中で最大規模 (1981 年の PAC 予算は約 90 万ドル）のプロジェクトで あるだけに，制度とその維持に関しての評価はか なり厳重に行われている。1981年 5 月ナイロビ開 催の第 9 回管理理事会では, UNEP と UNESCO の共同委託を受けた国際評価チーム（英国その他
の 6 か国 7 人）の作成した評価が報告された。評 価報告書は 6 項目に分けた現状分析・評価・勧告 から成り，310見体的勧告評価を次のように表現 している。

(1) INFOTERRA は運用開始後まだ日が浅 く,よく知られていないので, 利用が十分でな い。しかし，照会機構はうまく機能して括り， 今後開発を続けるならば，利用が実質的に増加 すると考光られる。

（2）利用者にとって, INFOTERRA は, 文献情 報と同様の役に立ち, また，他の方法では得ら れない情報に到達できる点で, 文献情報を補完 するものである。利用のコストは低く, 国際関 係の向上に役立つ。扣もな欠点は, 郵便に頼っ ているため遅いことであるが，通信手得の改良 が普及すれば，克服されるであろら。

結局, 改善が必要であるが, その見通しはあり, 文献情報を補完するものとして表現しているが, 欠点については別の見方もある。例えば，筆者が 日独科学技術協定に基づく第 5 パネル（情報ドク メンテーション) の第 2 回会合 (1980年11月東京) で，西独環境庁代表に INFOTERRA についての 見解をただしたところ，かなり批判的な意見を聞 かされた。利用者が 2 回の手数によって原情報に 
アクセス可能といら非能 率性を指摘し, 西独では 1 回で済むようにしてい るから, INFOTERRA の名称は表面に出さない といらことであった。た しかに，利用者の立場を 重視した意見であるが世 界的なネットワークを維 持するためには，国に よって違う感覚の中から 情報源の協力を得やすい 形式として作られた INFOTERRA の制度を でさるだけ尊重しなが ら，それぞれの国情に応 じたサービス制度を追加 することも必要ではない かと思われる。

日本の場合, INFORTERRA は国立公害研 究所の環境情報部の主要 事業である環境データ ベース（第 9 図参照）の 構築と運用の中に組み込 まれて, その整備に努め て打り, 各国の運用事情 等を参照しながら改善を 進めている。

\section{UNEP に関する 情報は何によっ て得られるか}

\subsection{UNEP 出版物}

一般に, 正式な情報確 認は文書や印刷物を入手 することによって得られ ることが多い。UNEP の 多彩な情報活動でも，そ

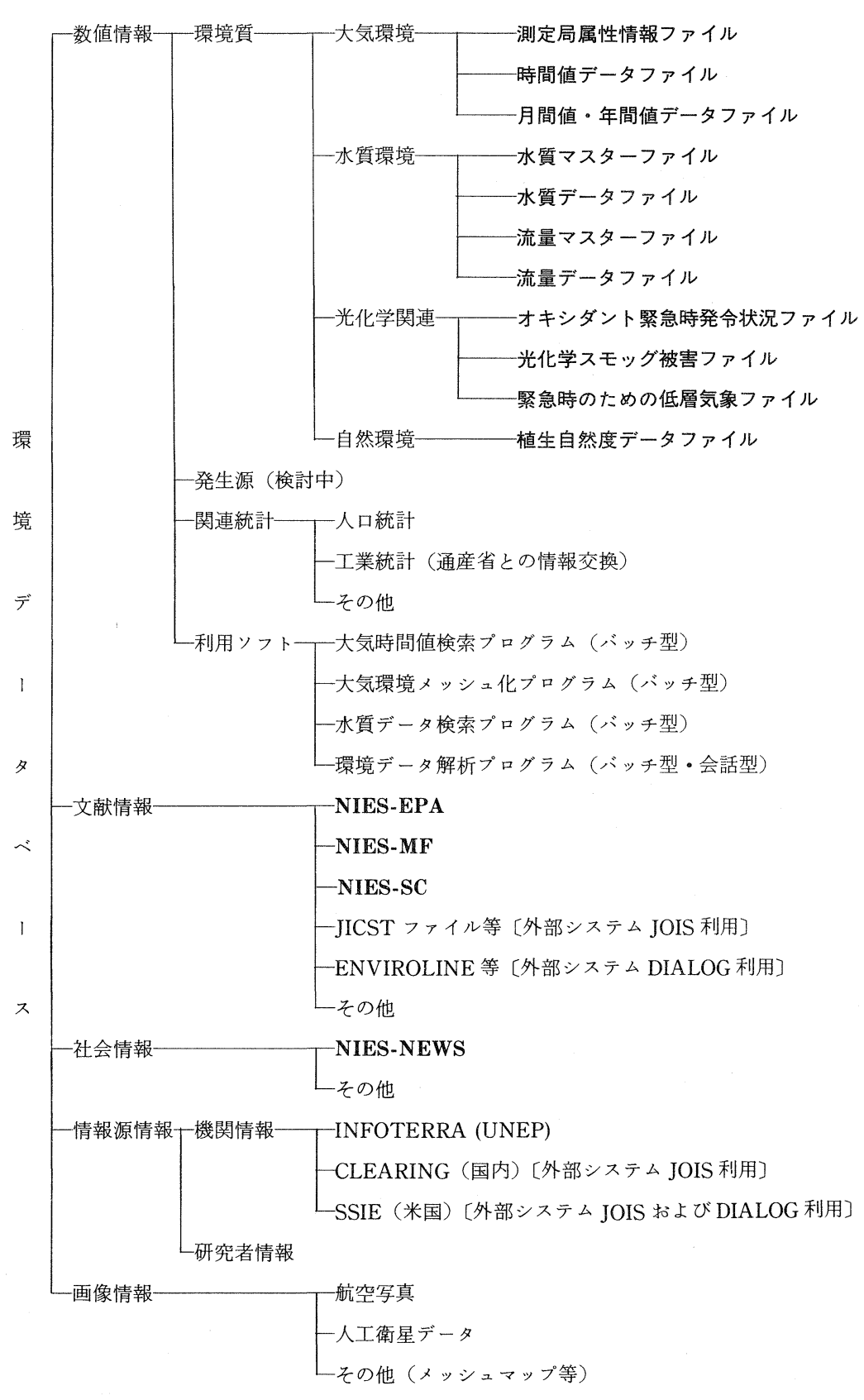

$\left(\begin{array}{l}\text { 太字は研究所が作成するファイル } \\ \text { 英字はオンライン検索用ファイル }\end{array}\right)$

第 9 図国立公害研究所の環境データベースの構成 
のために多くの出版物を発行している。しかし, 事務組織の成立後まだ日が浅いことと, 活動領域 が広範であることもあって，その出版活動を詳細 に知ることはかなり困難である。ここでは, UNEP が出版の責任を持つものと, 次に UNEP との契約に基づいて UNEP の情報が得られる出 版物, 沶よびその他の情報源となる出版物とに分 けて説明する。

1) UNEP Annual Review (ISBN 92807 10575)

発行 : UNEP, Nairobi, Kenya

UNEP の毎年の活動を総括した事業年報であ る。1981年度報告の場合，第 1 部が1981年の第 9 回管理理事会で報告されたTolba 議長の世界の 環境についての年間概況報告, 第 2 部が UNEP の各計画についての実施概況，第 3 部が招待論文 と付録になっている。

第 2 部の中に前に説明した 3 大内部プロジェク トをはじめとして環境基金に至るまでの 21 項目が あり, Informationの項では出版物和よび視聴覚 資料の発行についての説明がある。

\section{2) Special Publications}

“The World Environment, 1972-82”がその 例であるが，Mazingiraのよらな関連商業誌の特 集号への補助も含まれる。

3 ) UNEP Reports and Proceedings Series "A Training Manual on Biogas in China", "The Ecology and Utilization of African Inland Waters”, などがある。

4) UNEP Refference Series

“An Environmental Bibliography”がある。

5 ) UNEP Studies Series

"Environment and Development in Africa", “The Child in the Aflican Environment”など。

6) UNEP Executive Series

事業報告や政策提案などが多く, 前述の “UNEP Annual Review”もこの中に入るが，そ の他に “In Defence of the Earth : The Basic Texts", "The State of the Environment, Selected Topics”などがあり, 最後のものは毎年の管理
理事会での議長報告で Annual Review の一部に もなっているものである。

7) IRPTC 出版物

前に記した“IRPTC Bulletin”は原則として関 係機関配布で販売はされてないが, IRPTCの出 版物活動はかなり盛んであり，登録事務を説明し た “Register Attribute Series”, “Information Series”などがある。また，重要成果としての “IRPTC Data Profile Series” からは,

(1) Data Profiles for Chemicals for the Evaluation of their Hazards to the Environment of the Mediterranean Sea,

(2) Legal Data Profiles for Selected Chemicals 1980,

(3) Data Profile on Mercury といらように刊行が進んでいる。

8 ) Industry and Environment (ISSN 0378 9993).

発行: Industry \& Environment office, UNEP, 17rue Margueritte, 75017 Paris, France

年 4 回発行のレビュー誌の形態で, テーマ特集 の形式で編集されていることが多い。

9) UNITERRA (ISSN 0379 3192)

発行: Information Service of UNEP, P.O. Box30552, Nairobi, Kenya

UNEP の広報誌の性格を持っている隔月刊の 雑誌である。

10) INFOTERRA Bulletin.

発行: INFOTERRA, UNEP, Nairobi, Kenya 隔月刊の事業報告である。主にINFOTERRA ネットワークを構成する機関の相互連絡の機能を 持つように編集されている。

\subsection{UNEP 記事掲載誌}

UNEP 活動は環境に関連しての調整機能を含 むため, 各種の国際機関との共同プロジェクトが 多い。共同プロジェクトは個々の専門機関の機関 誌に紹介される。また, 環境関連の商業出版物の 中にUNEP との契約によって, UNEP の記事を 
揭載している場合がある。これらのらち主なもの を幾つか例示する。

1) Mazingira (ISSN 0250 6858)

発行: (英語版) Tycooly International Pub. Ltd., Dublin, Ireland

年 4 回発行で, 副題が The International Journal for Environment and Development なっている。発行にはUNEP の補助があり, News from UNEP といら数ページが毎号ある。

2) World Environment Report

発行: World Environment Center, Inc., Editorial Office, 605 Third Avenue, 17th floor, New York, NY 10158

月 2 回刊行の標準が 8 ページの情報誌で, UNEP の補助がある。Alexander Research \& Communications, Inc. との共同経営で, News and Information on International Resource Management の副題があり，世界各地の環境問題 に対する短い意見提示の場となっていて, UNEP を特に強調するわけではないが，関連のプログラ ムを論評するといら形式のものが見られる。

3 ) WMO Bulletin.

発行: WMO, Geneva, Switzerland

年 4 回発行, $\mathrm{WMO}$ (世界気象機関) の広報的論 説誌であるが, UNEP の 3 大内部プロジェクトの GEMS との共同事業がかなりの比重を占めるよ らになったので，それに関連した記事が掲載され ることが多い。

\section{4）か九さょら}

発行：陎ぎょらせい

環境庁編集協力の雑誌で隔月刊になっている。 UNEP に対応する国内責任官庁が環境庁であり (担当は国際課), かつナイロビの UNEP 本部に 常時何名かの職員が出向しているということも あって, UNEP 関係の記事は多い。

\section{3 その他の情報源}

本誌の目的に沿うためには, 前述のよらな公式 の公開情報としての出版物，そしてそれに次ぐ関 連出版物に加えるべき公開の情報収集手段を記す
必要がある。現在, 国際機関の多くはそれを主管 する官庁が定められているので，それら官庁の担 当部門を訪初て相談するのはひとつの方法であ り，それぞれの担当部門については前に述べた。

ここでは，文献検索等の手段がかなり有効であ り, 今後さらに整備されるものと思われるので, 利用者の立場で簡単に説明したい。この記事の終 わりに, 主として日本語の参考文献を掲載したが, 全体の約 $1 / 3$ はJ JOIS の検索によるものである。 1981年以降の収録といら制約を考学ると，筆者の 印象では大分成積が良いと考えたが，人によって は違らかもしれない。科学技術関係の雑誌に揭載 された情報関連報告は，それが技術的といらより， 事務的報告でも收録されているが，社会科学的雑 誌あるいはそれに近いと見られる雑誌になると収 録される機会がないよらである。また関連省庁の 資料類もない。国際機関の活動といら問題になる と, 同じ性格の論文でも, 掲載する専門誌の幅は かなり広い。社会科学系の文献データベースを国 内でも開発することが必要である。現在，かなり 多数の利用者が幾つかのデータベースを組み合わ せて使うことに慣れているので，データベースの 専門家に開拓していただきたい分野である。

\section{あとがき}

今までに，この講座で扱われてきた幾つかの国 際機関の多くは, その活動分野が専門化されたも ので，いわば専門機関であったが，UNEP には調 整機関としての機能が重視されていたので，その 情報活動は専門機関のように明確に表現できない 場合が多い。したがって, 情報活動についての情 報源を知ることがやや困難であった。また，原典 となる会議録や事業報告の類も入手し難いものが 多かったが, 国立衛試の化学物質情報部の中館室 長その他の方々に種々御教示をいただいた。な拉, 関係者等の多くの報告をつき合わせて，情報利用 者の立場でまとめることを考えたので，論文等の 個々の引用はせずに, 参考文献に一括して記した。 著者の方々にあわせて陉礼を申し上げる。 


\section{参考文献}

1）市川竜資：原子力の環境影響に関する UNEP 専 門家会議 保健物理14 [1]49-52（'79）

2 ）伊藤訓行, 渡辺和夫, 松尾義一, 連石久ゆき：環 境問題に関する国際機関等の諸活動環境研究 No.33 64-84 ('81)

3 ) 加藤久和：ナイロビ通信 第 1 信〜第 8 信 公害 と対策12〔9] 13 [12〕1976 1977

4 ) 加藤久和：国連環境計画 (UNEP), その理論と実

態 環境研究 No.39 51-64 1982

5 ) 環境庁長官官房国際課: 国連環境計画 (UNEP)

と第 8 回 UNEN 管理理事会の概要 p.34 1980

6 ) 国立衛生試験所：IRPTC (国際有害化学物質登録 制度）の概要 p.72 1979

7 ）国立公害研究所環境情報部：INFOTERRA 国内 情報源台帳（第 5 版補冊）国立公害研究所環境情報部 資料第 2 号 1983

8). 佐藤邦子：環境の現状 '77年に抢ける主要な問題 そついての UNEP 事務局長報告 環境情報科学 6 [4] 82-99 ('77)

9 ）佐藤邦子：国連に打ける最近の環境活動につい
て, UNEP の活動と’78年事務局長レポートから 環 境情報科学 7 〔3 3 97-103（'78）

10）竹中祐典：国際有害化学物質登録（IRPTC）制度 について 塩ビ食品衛生協議会会報 No.56 $1-7$ 1981

11）土屋璇, 春山暁美, 広崎昭太 : 国立公害研究所の 情報システムの現状と将来構想 情報管理 6 548一-559 ('80)

12）原文兵衛，五代利矢子，佐藤雄也，小林光，平石 尹彦，今井千郎：(特集)ストックホルム国連人間環境 会議十周年（対談と世界各地からの報告 4 編）かん きょ57〔3]6-34 1982

13）春山暁美：国際環境情報源照会システム（INFOTERRA）について 国立公害研究所調査報告 第 15 号 73-76 1980

14）春山暁美: 環境の情報源情報 環境情報科学 11〔2] $10-17$

15）藤森昭一，山崎圭，田中努，環境庁長官官房国際 課, 飯島考, 星野一昭, 加藤久和, 薄木三生 : (特集) 国連環境計画管理理事会特別会合を振り返って かん きょ5 7 〔5] 10-40（'82）

\section{識別の方法}

物を識別する場合, その方法として視覚, 聴 覚, 嗅覚, 触覚等があるが, 普通は視覚に頼る ことが多い。私達が普段なにげなく?使ってい る抢金にしても，それが 1 万円札か5,000円札 かあるいは1,000円札かは視覚で識別しているは ずである。だが, これが暗闇の中ではどうであろ う。券種によって多少の大きさの違いはあるに しても，その種類を自信をもって言い当てるこ とができるであろらか。特に，米国のようにド ル紙幣が皆同じ大きさの場合は，全く不可能で ある。

そこへいくと，オランダで発行されているギ ルダー（G1s）紙幣は，暗闇の中でも必ず識別で きるという魔法の紙幣である。魔法の種明かし は, 紙幣の左下に直径約 4 ミリの盛り上がった
丸い点が付いて拉り，指でなでて（つ交触覚 で識別)，それが何個付いているかで，金額が分 かるという仕組みである。ちなみに 1,000 Gls に は印がなく，以下 $100 \mathrm{Gls} 1$ 個，25Gls 2 個，10 Gls 3 個， 5 Gls 4 個の印が付いている。もちろ ん, この印は目の不自由な人のために付けられ たものである。

こうしてみると，俗に“Go Dutch”（割り勘 でいこう)等，扣金に関するオランダ人気質を皮 肉ともヤッカミともとれる言い方で表した表現が あるが，的を得ているようにもそうでないよう にも思われる。

な抏，日本でも59年中に発行予定の新紙幣に は, 点字識別マークが付けられるとのことであ る。 